\title{
Mengkaji Penerapan Blended Learning Menggunakan Metode Flipped Classroom di Perguruan Tinggi Agama Kristen
}

\author{
Rizky Permana \\ Sekolah Tinggi Agama Kristen Teruna Bhakti, Yogyakarta \\ permanarizky31@gmail.com
}

\begin{abstract}
The purpose of this research is to develop learning e-learning-based as a solution in improving attitudes, interests and competence of student learning. The essence of this study is to look for differences between learning competencies before and after the application of-based this method. The results showed a difference and the results of learning competencies were seen from the gain is 1 with high criteria. Thus it can be concluded that the results of the development of learning in blended the method flipped classroom can improve the learning competencies. This finding is the development of the blended learning method of a flipped classroom, a learning method that can be applied in Blended the method flipped classroom can be used as a reference in new learning.
\end{abstract}

Keywords: blended learning; e-learning; flipped classroom

\begin{abstract}
Abstrak: Tujuan dari penelitian ini adalah untuk mengembangkan pembelajaran berbasis e-learning sebagai solusi dalam meningkatkan sikap, minat dan kompetensi pembelajaran siswa. Inti dari penelitian ini adalah untuk mencari perbedaan antara kompetensi belajar sebelum dan sesudah penerapan berbasis metode ini. Hasil penelitian menunjukkan perbedaan dan hasil kompetensi belajar dilihat dari gain 1 dengan kriteria tinggi. Dengan demikian dapat disimpulkan bahwa hasil pengembangan pembelajaran pada kelas campuran dengan metode membalik kelas dapat meningkatkan kompetensi belajar. Temuan ini merupakan pengembangan dari metode blended learning kelas flipped, metode pembelajaran yang dapat diterapkan dalam Blended themethod kelas flipped dapat digunakan sebagai referensi dalam pembelajaran baru.
\end{abstract}

Kata kunci: metode belajar; blended learning; e-learning; flipped classroom

\section{Pendahuluan}

Perkembangan dunia teknologi informasi saat ini berkembang sangat pesat seiring dengan penemuan dan pengembangan ilmu di bidang informasi sehingga dapat menciptakan alat yang mendukung pengembangan teknologi informasi, mulai dari sistem informasi hingga alat komunikasi. (Abeysekera, Lakmal and Dawson, Phillip, 2015). Dewasa ini orang tidak lagi mendapatkan informasi hanya melalui media cetak, radio dan televisi namun menjadikan internet sebagai sebagai cara baru melakukan pencarian informasi. Internet juga merupakan salah satu sumber informasi utama. Internet saat ini banyak dimainkan peran dalam kehidupan manusia.

Kemajuan teknologi adalah sesuatu yang tidak bisa dihindari dalam kehidupan ini, karena kemajuan teknologi akan berjalan sesuai dengan kemajuan ilmu pengetahuan (Bell, Mathew R., 2015). Kemajuan teknologi digunakan dalam berbagai bidang, seperti melakukan pekerjaan belajar mengajar, mengelola keuangan, mendengarkan musik, menonton video dan menikmati permainan. Perkembangan teknologi juga berdampak pada 
sektor pelatihan di Indonesia, banyak instruktur dan widyaiswara yang mengembangkan media pembelajaran menggunakan bantuan internet sebagai alat pembelajaran

Dengan fenomena yang muncul ini penelitian ini mencoba menghubungkan dengan kondisi pelatihan yang ada di Pusat Pelatihan Manajemen dan Kepemimpinan (PPMKP). Sebagai lembaga pelatihan yang berada dalam naungan Kementerian Pertanian, PPMKP yang memiliki domain pelatihan di bidang kepemimpinan dan manajemen seringkali mengalami kesulitan atau minimal menerima keluhan bahwa banyak calon peserta ingin mengikuti pelatihan namun terkendala dengan waktu dan biaya. Namun mereka juga tidak ingin hanya bertemu melalui media internet atau dunia maya saja karena mereka membutuhkan tatap muka untuk memantapkan memahami materi. Penugasan ke luar kota atau lembur pekerjaan kantor menjadi penyebab kesulitan mereka.

Hal ini ternyata juga berbanding lurus dengan kondisi mereka ketika berada didalam kampus PPMKP, dimana kepadatan pekerjaan mereka sehingga ketika mereka berada di pelatihan tertentu mereka justru merasa lelah yang dilihat dari sikap belajar dan minat belajar yang kurang karena kelelahan hal ini diindikasikan dari kurangnya peserta yang aktif di kelas dan akhirnya berdampak pada hasil kompetensi peserta yang tidak baik pada skor Pre - Post Test maupun Ujian Akhiruntuk pelatihan tertentu. Hal ini akhirnya inovasi dalam model pembelajaran menjadi dibutuhkan di mana inovasi tersebut memiliki target dapat meningkatkan sikap, minat dan kompetensi belajar peserta.

Salah satu inovasi pembelajaran yang perlu dilakukan untuk mengatasi masalah ini adalah dengan menggabungkan pembelajaran face to face (konvensional) dengan $e$ learning dan menggunakan metode flipped learning. Metode ini sendiri dijelaskan sebagai suatu metode di mana peserta mendapatkan materi melalui e-learning dan pembelajaran tatap muka yang diisi dengan latihan atau diskusi. Diharapkan bahwa peserta akan lebih siap untuk menerima materi, diskusi dan latihan saat bertatap muka. Alasan menggunakan blended learning adalah beberapa hasil penelitian menunjukkan bahwa ada perbedaan yang signifikan dalam motivasi belajar antara kelas konvensional dan kelas menggunakan blended learning, ada perbedaan prestasi belajar secara signifikan antara kelas konvensional dan kelas menggunakan blended learning.

Tujuan akhir dari penelitian ini adalah 1) untuk menguji kelayakan pengembangan metode campuran blended learning flipped classroom; dan 2) menguji efektivitas pengembangan sikap terhadap pembelajaran, minat dan kompetensi belajar peserta dalam menerima metode flipped classroom

\section{Metode Penelitian}

Dalam penelitian ini penulis menganut metode penelitian dari Sugiyono bahwa R \& D memiliki sepuluh tahap, yaitu 1) potensi dan masalah; 2) pengumpulan data; 3) desain produk; 4) validasi desain; 5) desain revisi; 6) pengujian produk; 7) revisi produk; 8) penggunaan percobaan; 9) revisi produk; dan 10) massa produksi. Dalam penelitian ini hal itu disederhanakan prosedur penelitiannya dalam bentuk: 1) tahap proposisi; 2) tahap pengembangan; 3) tahap validasi; dan 4) tahap implementasi. Langkah pertama yang harus adalah penelitian awal terkait pembelajaran yang akan dikembangkan. Berdasarkan pendahuluan, 
penelitian ini merencanakan pembelajaran yang akan menjadi solusi yaitu pengembangan pembelajaran dicampur dengan metode flipped classroom

Instrumen yang digunakan dalam penelitian ini adalah kuesioner serta pretest dan posttest. (Sugiyono, 2015) menjelaskan bahwa dalam dunia pendidikan ada 2 (dua) jenis instrumen, yaitu instrument dalam bentuk tes untuk mengukur prestasi belajar dan instrumen non-tes untuk mengukur sikap.Teknik pengumpulan data untuk sikap dan minat belajar peserta menggunakan angket yang didistribusikan sebelum dan sesudah penerapan metode pembelajaran eksperimen. Selain dari kuesioner, peneliti juga mengamati sikap dan minat peserta sebelum dan sesudah aplikasi metode pembelajaran. Untuk mengukur kompetensi belajar peserta peneliti menggunakan metode tes,

\section{Hasil Dan Pembahasan}

Hasil penelitian peserta kelas kontrol sebelum perlakuan lebih tinggi dibandingkan kelas eksperimen. Sedangkan, setelah perlakuan hasil belajar peserta kelas eksperimen lebih tinggi dibandingkan kelas kontrol. Rata-rata nilai pretest dan posttest peserta kelas eksperimen lebih tinggi dibandingkan peserta kelas kontrol, dengan $\mathrm{KKM}=76$. Dari penelitian didapatkan hasil perbedaan hasil belajar antara peserta kelas eksperimen dan kelas kontrol dapat dilakukan menggunakan uji statistik yang sesuai terhadap data hasil angket. Data hasil angket peserta diolah menggunakan SPSS for Windows versi 23.0. Hasil angket sebelum dilakukan uji hipotesis, terlebih dahulu dilakukan uji prasyarat, yaitu uji normalitas dengan menggunakan uji Shapiro-Wilk.

Berdasarkan hasil uji normalitas angket awal, diperoleh nilai signifikansi pada kelas kontrol dan kelas eksperimen masing-masing sebesar 0,622 dan 0,221. Data dikatakan berdistribusi normal jika Sig $\geq 0,05$, sehingga data hasil angket awal pada kedua kelas tersebut berdistribusi normal. Setelah uji normalitas dan diperoleh data berdistribusi normal, selanjutnya dilakukan uji homogenitas menggunakan uji Levene. Berdasarkan uji homogenitas data hasil angket awal dengan uji Levene diperoleh nilai signifikansi sebesar 0,001 (Sig < 0,05), yang berarti data tersebut tidak homogen.

Selanjutnya, untuk menguji hipotesis hasil belajar awal digunakan uji statistik, yaitu uji t sampel independent dengan taraf nyata $=5 \%$. Karena varian sampel tidak homogen maka digunakan uji t Equals Variances Not Assumed, diperoleh nilai Sig.(2tailed) sebesar 0,763. Karena nilai Sig.(2-tailed) $\geq 0,05$, maka Ho diterima dan Ha ditolak. Hal tersebut menunjukkan bahwa tidak terdapat perbedaan hasil belajar antara peserta kelas kontrol dan peserta kelas eksperimen sebelum perlakuan.

Karena hasil belajar peserta sebelum perlakuan pada kedua kelas tersebut sama, maka untuk menguji hipotesis hasil belajar, skor yang diolah adalah skor angket akhir. Berdasarkan hasil uji normalitas angket akhir, diperoleh nilai signifikansi pada kelas kontrol dan kelas eksperimen masing-masing sebesar 0,278 dan 0,006. Data dikatakan berdistribusi normal jika Sig $\geq 0,05$, sehingga data hasil angket akhir kelas kontrol berdistribusi normal. Sedangkan, data hasil angket akhir kelas eksperimen tidak berdistribusi normal. 
Karena data hasil angket akhir salah satu kelas tidak berdistribusi normal, maka data hasil angket akhir secara keseluruhan dianggap tidak berdistribusi normal. Selanjutnya, untuk menguji hipotesis kepercayaan diri peserta digunakan uji statistik nonparametrik menggunakan uji U-Mann Whitney dengan taraf nyata $=5 \%$. Berdasarkan hasil uji hipotesis data hasil angket akhir, diperoleh nilai Asymp.Sig(2-tailed) sebesar 0,000. Karena nilai Asymp.Sig (2-tailed) < 0,05, maka Ha diterima dan Ho ditolak, sehingga dapat disimpulkan bahwa terdapat perbedaan hasil belajar antara peserta yang diajar menggunakan model pembelajaran flipped classroom dengan peserta yang diajar menggunakan model pembelajaran konvensional.

Selain pengaruh metode terhdap hasil belajar, diukur juga dalam penelitian ini adalah effect size dari metode terhadap hasil belajar. Besarnya pengaruh penggunaan model pembelajaran flipped classroom terhadap hasil belajar peserta ditentukan secara kuantitatif menggunakan rumus effect size, dan diperoleh harga effect size sebesar 0,74 sehingga termasuk kategori tinggi. Jika harga effect size dikonversikan di bawah kurva lengkung normal standar dari 0 s/d Z yang kemudian dikalikan $100 \%$ menunjukkan bahwa penggunaan model pembelajaran flipped classroom memberikan pengaruh sebesar 29,39\% terhadap hasil belajar peserta

Walaupun ada banyak keterbatasan dengan metode flipped classroom dan tidak ada penelitian empiris untuk mendukung penggunaannya, banyak informasi laporan instruktur mempertahankan bahwa hal itu dapat digunakan sebagai strategi mengajar yang berharga pada setiap tingkat pendidikan, tergantung peserta didik, sumber daya, dan waktu seseorang. Apalagi tampaknya cocok untuk penegetahuan mengajar yang prosedural, salah satu dari empat jenis pengetahuan umum yang dijelaskan dalam Taksonomi Bloom yang telah diperbaiki menurut Anderson dkk. dalam Natalie (2012).

Sebagai contoh, materi pengetahuan prosedural adalah pengetahuan tentang bagaimana melakukan sesuatu. Oleh karena itu video ceramah flipped classroom tentang bagaimana memecahkan permasalahan dimana seorang instruktur menjelaskan dan model bagaimana memecahkan jenis masalah akan menjadi baik dalam penggunaan strategi ini. Pengetahuan prosedural yang kompleks juga dapat diajarkan menggunakan strategi flipped classroom meskipun penopang dan potongan konten akan sangat penting tidak hanya untuk memastikan bahwa video pendek, tetapi juga untuk memastikan bahwa semua langkah prosedur diperkenalkan memadai sehingga peserta benar-benar memahami.

Dari uraian diatas dapat ditarik benang merah terhadap kelebihan dan kekurangan penerapan flipped classroom, terutama untuk diterapkan di Indonesia. Adapun kelebihan dan kekuarangan tersebut adlaah sebagai berikut: Kelebihan flipped classroom, yaitu:

Pertama, peserta dapat mengulang-ulang video tersebut hingga ia benar-benar paham materi, tidak seperti pada pembelajaran biasa, apabila murid kurang mengerti maka widyaiswara harus menjelaskan lagi hingga peserta dapat mengerti sehingga kurang efisien. 
Kedua, peserta dapat mengakses video tersebut dari manapun asalkan memiliki koneksi internet yang cukup, bahkan bisa didownload dan lebih puas untuk menontonnya berulang-ulang.

Ketiga, efisien, karena peserta diminta untuk mempelajari materi di rumah dan pada saat di kelas, peserta dapat lebih memfokuskan kepada kesulitannya dalam memahami materi ataupun kemampuannya dalam menyelesaikan soal-soal berhubungan dengan materi tersebut.

Namun demikian, ada juga kekurangan flipped classroom, yaitu:

Pertama, untuk menonton video, setidaknya diperlukan satu unit computer atau laptop. Hal ini akan menyulitkan peserta yang tidak memiliki komputer/laptop, mereka harus ke warnet untuk mengakses video tersebut.

Kedua, diperlukan koneksi internet yang lumayan bagus untuk mengakses video tersebut. Terutama di daerah yang koneksi internetnya memasuki daftar lambat, terutama apabila filenya berukuran besar, maka akan membutuhkan waktu yang cukup lama untuk membuka atau mengunduhnya. Ada cukup banyak peserta yang gaptek sehingga mereka memerlukan waktu yang lebih untuk mengakses video tersebut.

Ketiga, peserta mungkin perlu banyak penopang untuk memastikan mereka memahami materi yang disampaikan dalam video dan peserta tidak mampu mengajukan pertanyaan ke instruktur atau rekan-rekan mereka jika menonton video saja.

Keempat, dalam implementasinya flipped classroom hanya bisa diterapkan di lembagayang pesertanya sudah memiliki sarana dan prasarana yang sudah memadai mengingat pada strategi ini menuntut peserta untuk menonton video tutorial di rumah.

Adapun langkah - langkah pembelajaran flipped classroom adalah sebagai berikut: Pertama, sebelum tatap muka, peserta diminta untuk belajar mandiri di rumah mengenai materi untuk pertemuan berikutnya, dengan menonton video pembelajaran karya widyaiswara itu sendiri ataupun video pembelajaran dari hasil upload orang lain. Kedua, pada pembelajaran di kelas, peserta didik dibagi menjadi beberapa kelompok heterogen. Ketiga, peran widyaiswara pada saat kegiatan belajar berlangsung adalah memfasilitasi berlangsungnya diskusi dengan metode kooperatif learning. Di samping itu, widyaiswara juga akan menyiapkan beberapa pertanyaan (soal) dari materi tersebut. Keempat, widyaiswara memberikan kuis/tes sehingga peserta sadar bahwa kegiatan yang mereka lakukan bukan hanya permainan, tetapi merupakan proses belajar, serta widyaiswara berlaku sebagai fasilitator dalam membantu peserta dalam pembelajaran serta menyelesaikan soal soal yang berhubungan dengan materi.

\section{Kesimpulan}

Flipped classroomm memiliki kesempatan untuk menyebabkan pergeseran signifikan dalam cara instruksi yang disampaikan. Menggunakan teknologi, instruktur sekarang dapat memberikan alternatif untuk model belajar berbasis tradisional dengan menerapkan metode penggabungan pembelajaran yang menggabungkan manfaat dari instruksi langsung dan pembelajaran aktif untuk melibatkan para siswa dalam proses pembelajaran. Pelaksanaan model flipped classroom dalam lingkungan komputasi satu ke satu akan bernilai 
menjelajahi lebih lanjut. Lebih fokus dapat ditempatkan pada kelas kemampuan campuran dan kemampuan yang lebih tinggi. Perancah dapat lebih disempurnakan baik untuk kegiatan rumah dan kegiatan kelas. Salah satu perbaikan yang mungkin termasuk membedakan pertanyaan membimbing digunakan dalam kegiatan rendah di bawah pertanyaan dalam taksonomi Bloom untuk kegiatan rumah dan pertanyaan tatanan yang lebih tinggi untuk kegiatan kelas. Peserta pelatihan melaporkan tingkat stress yang lebih rendah dalam jenis lingkungan kelas dibandingkan dengan kelas-kelas lain. Sementara nilai kelas eksperimental menunjukkan peningkatan yang signifikan. Secara keseluruhan, peserta memiliki perasan positif terhadap hal yang terkait untuk bisa memilih tugas mereka sendiri dan mengeksplorasi konsep-konsep yang mereka temukan menarik lebih mendalam yang terdapat dalam metode flipped classroom.

Melihat keuntungan dan manfaat yang dapat dicapai dalam proses belajar ini, khususnya di Perguruan Tinggi Keagamaan Kristen, maka penggunaannya dapat diterapkan di Sekolah Tinggi Agama Kristen atau Sekolah Tinggi Teologi. Terlebih lagi dalam menghadapi kemajuan zaman dan keterbatasan jarak oleh karena pekerjaan dan kondisi-kondisi tertentu metode ini dapat digunakan oleh dosen-dosen sekolah tinggi teologi, membantu memberikan efektivitas penyampaian belajar.

\section{Referensi}

Abeysekera, Lakmal and Dawson, Phillip. (2015). Motivation and cognitive load in the flipped classroom: definition, rationale and a call for research. Higher education research \& development, vol. 34, no. 1, pp. 1-14.

Al-Zahrani Abdulrahman M. (2015). From passive to active: The impact of the flipped classroom through social learning platforms on higher education students' creative thinking. British Journal of Educational Technology. Vol 46 No 6, 1133-1148

Lo, C. K., \& Hew, K. F. (2017). A critical review of flipped classroom challenges in K-12 education: Possible solutions and recommendations for future research. Research and Practice in Technology Enhanced Learning, 12(1).

O'Flaherty, J., \& Phillips, C. (2015). The use of flipped classrooms in higher education: a scoping review. The Internet and Higher Education, 25, 85-95.

Zainuddin, Z., \& Halili, S.H. (2016). Flipped classroom research and trends from different fields of study. International Review of Research in Open and Distributed Learning, 17(3), 313-340.

Roach, T. (2014). Studentperceptions toward flipped classroom: New methods to increase interaction and active learning in economics. International Review of Economics Education, 17,74-84. 